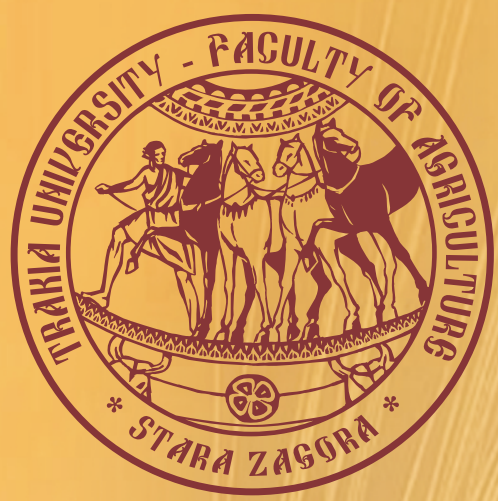

ISSN $1313-8820$ (print)

ISSN 1314 - 412X (online)

Volume 9 , Number 4

December 2017

\title{
AGRICULTURAL
}

\section{SCIENCE AND TECHNOLOGY}

\section{7}

An International Journal Published by Faculty of Agriculture, Trakia University, Stara Zagora, Bulgaria 


\section{Editor-in-Chief}

Georgi Petkov

Faculty of Agriculture

Trakia University, Stara Zagora

Bulgaria

E-mail: gpetkov@af.uni.sz.bg

\section{Co-Editor-in-Chief}

Dimitar Panayotov

Faculty of Agriculture

Trakia University, Stara Zagora

Bulgaria

\section{Editors and Sections}

\section{Genetics and Breeding}

Tsanko Yablanski (Bulgaria)

Atanas Atanasov (Bulgaria)

Svetlana Georgieva (Bulgaria)

Nikolay Tsenov (Bulgaria)

Max Rothschild (USA)

Ihsan Soysal (Turkey)

Horia Grosu (Romania)

Stoicho Metodiev (Bulgaria)

Bojin Bojinov (Bulgaria)

\section{Nutrition and Physiology}

Nikolai Todorov (Bulgaria)

Peter Surai (UK)

Ivan Varlyakov (Bulgaria)

George Zervas (Greece)

Vasil Pirgozliev (UK)

\section{Production Systems}

Radoslav Slavov (Bulgaria)

Dimitar Pavlov (Bulgaria)

Bogdan Szostak (Poland)

Banko Banev (Bulgaria)

Georgy Zhelyazkov (Bulgaria)

\section{Agriculture and Environment}

Martin Banov (Bulgaria)

Peter Cornish (Australia)

Vladislav Popov (Bulgaria)

Tarek Moussa (Egypt)

\section{Product Quality and Safety}

Stefan Denev (Bulgaria)

Vasil Atanasov (Bulgaria)

Roumiana Tsenkova (Japan)

\section{English Editor}

Yanka Ivanova (Bulgaria)
Scope and policy of the journal

Agricultural Science and Technology /AST/

- an International Scientific Journal of Agricultural and Technology Sciences is published in English in one volume of 4 issues per year, as a printed journal and in electronic form. The policy of the journal is to publish original papers, reviews and short communications covering the aspects of agriculture related with life sciences and modern technologies. It will offer opportunities to address the global needs relating to food and environment, health, exploit the technology to provide innovative products and sustainable development. Papers will be considered in aspects of both fundamental and applied science in the areas of Genetics and Breeding, Nutrition and Physiology, Production Systems, Agriculture and Environment and Product Quality and Safety. Other categories closely related to the above topics could be considered by the editors. The detailed information of the journal is available at the website. Proceedings of scientific meetings and conference reports will be considered for special issues.

\section{Submission of Manuscripts}

There are no submission / handling / publication charges.

All manuscripts written in English should be submitted as MS-Word file attachments via e-mail to editoffice@agriscitech.eu. Manuscripts must be prepared strictly in accordance with the detailed instructions for authors at the website

www.agriscitech.eu and the instructions on the last page of the journal. For each manuscript the signatures of all authors are needed confirming their consent to publish it and to nominate on author for correspondence.

They have to be presented by a submission letter signed by all authors. The form of the submission letter is available upon from request from the Technical Assistance or could be downloaded from the website of the journal. Manuscripts submitted to this journal are considered if they have submitted only to it, they have not been published already, nor are they under consideration for publication in press elsewhere. All manuscripts are subject to editorial review and the editors reserve the right to improve style and return the paper for rewriting to the authors, if necessary. The editorial board reserves rights to reject manuscripts based on priorities and space availability in the journal.

The journal is committed to respect high standards of ethics in the editing and reviewing process and malpractice statement. Commitments of authors related to authorship are also very important for a high standard of ethics and publishing. We follow closely the Committee on Publication Ethics (COPE), http://publicationethics.org/resources/guid elines

The articles appearing in this journal are indexed and abstracted in: DOI, EBSCO Publishing Inc., AGRIS (FAO) and DOAJ.

The journal is accepted to be indexed with the support of a project № BG051P00013.3.05-0001 "Science and business" financed by Operational Programme "Human Resources Development" of EU. The title has been suggested to be included in SCOPUS (Elsevier) and Electronic Journals Submission Form (Thomson Reuters).

The journal is freely available without charge to the user or his/her institution. Users can read, download, copy, distribute, print, search, or link to the full texts of the articles, or use them for any other lawful purpose, without asking prior permission from the publisher or the author.

This issue is printed with the financial support by Contract No DNP 0521/20.12.2016, financed from Fund 'Scientific Research' grant Bulgarian scientific Periodicals.

\section{Address of Editorial office:}

Agricultural Science and Technology Faculty of Agriculture, Trakia University

Student's campus, 6000 Stara Zagora

Bulgaria

Telephone: +35942699330 $+35942699446$

www.agriscitech.eu

Technical Assistance:

Nely Tsvetanova

Telephone: +359 42699446

E-mail:editoffice@agriscitech.eu 


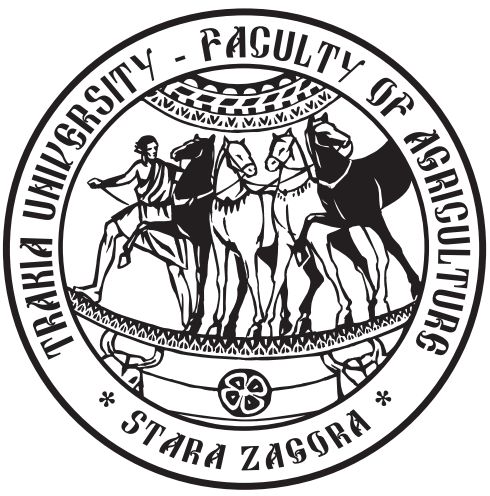

AGRICULTURAL

SCIENCE AND TECHNOLOGY

\section{7}

An International Journal Published by Faculty of Agriculture,

Trakia University, Stara Zagora, Bulgaria 


\title{
Genetics and Breeding
}

\section{Variation in the agronomic and morphological traits in spring barley}

\author{
N. Dyulgerov, B. Dyulgerova* \\ Institute of Agriculture, 8400 Karnobat, Bulgaria \\ (Manuscript received 4 July 2017; accepted for publication 27 October 2017)
}

\begin{abstract}
The study was conducted to examine the variation in the agronomic and morphological traits in spring barley. For this purpose, 22 lines from the ICARDA High Input Barley Program for favorable environment and 3 check varieties (Rihane-03, VMorales and Veslets) were tested in an alpha-lattice design with two replications at the Institute of Agriculture - Karnobat, Bulgaria in 2014 and 2015 growing season. The traits days to heading, plant height, number of tillers per plant, flag leaf length, flag leaf width, spike length, awn length, peduncle length, spikelet number per spike, grain number per spike, grain weight per spike, 1000 grains weight, grain yield, powdery mildew (Erysiphe graminis f. sp. hordei), net blotch (Pyrenophora teres f. teres) and stripe rust (Puccinia striiformis $f$. sp. hordei) infection were studied. Significant differences between lines for all studied traits were found. The number of fertile tillers per plant was significantly positively correlated with grain yield. Lines expressed higher grain yields, shorter stem, better tolerance to net blotch and stripe rust than Bulgarian check variety Veslets were identified. These genotypes can, therefore, be used as parents for the improvement of spring barley.
\end{abstract}

Keywords: barley, agronomic traits, morphological traits, breeding

\section{Introduction}

Barley (Hordeum vulgare L.) is one of the main crops in many areas of the world, including Bulgaria. The main objectives of the Bulgarian barley breeding programs at the Institute of Agriculture, Karnobat are to develop varieties of barley with improved yield and nutritional quality adapted to changing agrometeorological conditions (Popova et al., 2009; Vulchev et al., 2009; Valcheva et al., 2013; Gocheva and Vulchev, 2014; Dimova, 2015). Climatic conditions in Southeast Bulgaria show large and unpredictable variations across different cropping seasons (Penchev and Zarkov, 2004). Moreover, Olesen et al. (2011) predict that the climate change will increase the occurrence of undesirable years for crop production. As a response to these changeable environmental conditions, high yielding barley with good resistance to lodging and resistance to leaf diseases with phonology conforming to ecological conditions is demanded.

Genetic diversity is the base of plant breeding and is one of the important components of biological systems stability. Variability in terms of genetic divergence for agronomic traits is the key component of barley breeding programs. Without including new germplasm in breeding, there is an increased risk of genetic vulnerability as a consequence of pathogen population evolution, loss of resistance genes and the appearance of new yield constraints (Condon et al., 2008; Mikel and Kolb, 2008). Continued gains in yield and agronomic traits require introgression of new alleles from exotic germplasm and elite germplasm from other breeding programs.

The aim of the study was to examine the variation in the agronomic and morphological traits in spring barley lines from the ICARDA High Input Barley Program under the conditions of
Southeast Bulgaria and to evaluate the possibility of their use in breeding work.

\section{Material and methods}

The experimental work was conducted during the 2015 and 2016 growing seasons in the experimental field of the Institute of Agriculture - Karnobat, Southeastern Bulgaria. The soil of the experimental field was slightly acid $(\mathrm{pH}=6.2)$ Pellic Vertisol.

The trial consisted of 22 lines of the ICARDA High Input Barley Program for favorable environment - 2015 and 3 check varieties (Rihane-03, VMorales and Veslets). Veslets is a six-row facultative variety and the national standard for feed barley. The experimental design was an alpha-lattice with two replications. Each plot consisted of 6 rows $2.5 \mathrm{~m}$ long with row spacing of $30 \mathrm{~cm}$. Days to heading were calculated from the date of sowing till the date when $50 \%$ of the spikes had emerged.

Disease levels were visually assessed at GS49-50 (Zadoks et al., 1974) when symptoms were at their maximum. The disease was measured as \% green leaf area covered in symptoms on the flag and second leaf. Diseases scored included powdery mildew (Erysiphe graminis f. sp. hordei), net blotch (Pyrenophora teres f. teres) and stripe rust (Puccinia striiformis f. sp. hordei).

Four central rows $\left(2.25 \mathrm{~m}^{2}\right)$ were harvested manually to measure grain yield. 1000-grain weight was measured from the sample grain yield.

The traits: flag leaf length $(\mathrm{cm})$, flag leaf width $(\mathrm{cm})$, plant height $(\mathrm{cm})$, spike length $(\mathrm{cm})$, awn length $(\mathrm{cm})$, peduncle length $(\mathrm{cm})$, spikelet number per spike, grain number per spike, grain weight per spike $(\mathrm{g})$, tiller number per plant were recorded on 25 randomly

*e-mail: bdyulgerova@abv.bg 
selected plants in each replication for each genotype. The significance of differences among means was compared by using Least Significant Difference (LSD) test at the 0.05 level. The data from the two years were summarized and Pearson correlation coefficients were estimated. For statistical analyses the computer software system of SPSS 16.00 for Windows 16.0 (SPSS Inc., 2007) was used.

\section{Results and discussion}

Mean values and their comparisons obtained using the LSD procedure for the studied traits of 25 barley genotypes are presented in Table 1. Flag leaf length varied from $16.70 \mathrm{~cm}$ (IBYT-HI-13) to $24.59 \mathrm{~cm}$ (IBYT-HI-19) and flag leaf width ranged from $1.03 \mathrm{~cm}$ (IBYT-HI-7) to $1.79 \mathrm{~cm}$ (IBYT-HI-2). Minimum days to heading of 68 days were taken by line IBYT-HI-20, whereas maximum days to heading of 79 days were recorded for line IBYT-HI-9. Lines IBYT-HI1, IBYT-HI-5, IBYT-HI-13, IBYT-HI-17, IBYT-HI-18 and IBYT-HI-20 had significantly shorter stem compared to the national standard Veslets. Line IBYT-HI-5 had minimum plant height $-68.17 \mathrm{~cm}$, while IBYT-HI-14 had maximum height $-86.50 \mathrm{~cm}$. The awn length ranged from $11.25 \mathrm{~cm}$ to $14.50 \mathrm{~cm}$. Peduncle length varied from $20.13 \mathrm{~cm}$ (IBYT-HI-19) to $35.50 \mathrm{~cm}$ (IBYT-HI-14). Peduncle length has been suggested as a useful indicator of yield capacity in dry environments in wheat (Asseng and van Herwaarden, 2003; Niari Khamssi and Najaphy, 2012).

The spike length in the studied genotypes varied from $7.43 \mathrm{~cm}$ (Rihane-03) to $10.63 \mathrm{~cm}$ (IBYT-HI-15). Spikelet number per spike and grain number per spike varied from 63.65 (IBYT-HI-19) to 78.75 (IBYT-HI-3) and from 38.25 (IBYT-HI-11) to 57.50 (IBYT-HI-10) in six-row genotypes. In two-row lines spikelet number per spike was from 26.73 for IBYT-HI-13 to 31.65 for IBYT-HI-14 and grain number per spike ranged from 18.35 (IBYT-HI-13) to 24.00 (IBYT-HI-7). The grain number is regarded as a main barley yield component and increased grain number has been produced by spikes per unit area or more grains per spike due to the higher spikelet number or higher spikelet fertility. There was large variation in the spikelet fertility

Table 1. Mean values of the studied traits in 25 barley genotypes (2015-2016)

\begin{tabular}{|c|c|c|c|c|c|c|c|c|c|}
\hline Lines & Row type & $\begin{array}{l}\text { Flag leaf } \\
\text { length, } \mathrm{cm}\end{array}$ & $\begin{array}{l}\text { Flag leaf } \\
\text { width, cm }\end{array}$ & $\begin{array}{l}\text { Days to } \\
\text { heading }\end{array}$ & $\begin{array}{c}\text { Plant height, } \\
\mathrm{cm}\end{array}$ & $\begin{array}{c}\text { Awn length, } \\
\mathrm{cm}\end{array}$ & $\begin{array}{l}\text { Peduncle } \\
\text { length, } \mathrm{cm}\end{array}$ & $\begin{array}{c}\text { Spike } \\
\text { length, } \mathrm{cm}\end{array}$ & $\begin{array}{l}\text { Spikelet number } \\
\text { per spike }\end{array}$ \\
\hline IBYT-HI-1 & 2 & 20.05 & 1.18 & 77.50 & 72.84 & 14.25 & 26.80 & 9.63 & 26.80 \\
\hline IBYT-HI-2 & 6 & 19.95 & 1.79 & 76.00 & 85.50 & 12.45 & 24.13 & 9.35 & 73.75 \\
\hline IBYT-HI-3 & 6 & 17.75 & 1.52 & 78.25 & 77.67 & 11.95 & 23.75 & 8.80 & 78.75 \\
\hline IBYT-HI-4 & 6 & 19.72 & 1.57 & 74.75 & 82.75 & 13.25 & 31.00 & 10.00 & 72.75 \\
\hline IBYT-HI-5 & 6 & 18.43 & 1.66 & 76.00 & 68.17 & 13.80 & 28.00 & 8.85 & 72.50 \\
\hline IBYT-HI-6 & 6 & 18.10 & 1.69 & 74.50 & 73.00 & 12.50 & 26.38 & 8.73 & 75.75 \\
\hline IBYT-HI-7 & 2 & 17.15 & 1.03 & 76.25 & 81.00 & 11.25 & 30.50 & 9.08 & 27.25 \\
\hline |BYT-HI-8 & 6 & 18.85 & 1.42 & 77.50 & 76.58 & 14.50 & 30.25 & 9.03 & 72.13 \\
\hline IBYT-HI-9 & 6 & 20.26 & 1.58 & 79.00 & 75.92 & 13.75 & 23.00 & 8.00 & 68.13 \\
\hline IBYT-HI-10 & 6 & 21.21 & 1.29 & 76.00 & 85.00 & 13.75 & 31.13 & 9.63 & 76.53 \\
\hline IBYT-HI-11 & 6 & 22.42 & 1.45 & 76.50 & 83.75 & 13.63 & 25.38 & 10.00 & 72.63 \\
\hline IBYT-HI-12 & 2 & 17.98 & 1.15 & 76.00 & 84.58 & 11.71 & 30.15 & 10.61 & 31.65 \\
\hline IBYT-HI-13 & 2 & 16.70 & 1.25 & 76.25 & 73.25 & 11.63 & 32.38 & 9.13 & 26.73 \\
\hline IBYT-HI-14 & 2 & 22.89 & 1.09 & 77.25 & 86.50 & 12.38 & 35.50 & 9.70 & 30.00 \\
\hline IBYT-HI-15 & 2 & 23.54 & 1.12 & 69.50 & 78.75 & 12.50 & 33.88 & 10.63 & 28.00 \\
\hline IBYT-HI-16 & 6 & 18.53 & 1.45 & 75.25 & 77.84 & 12.25 & 26.13 & 10.10 & 71.80 \\
\hline IBYT-HI-17 & 6 & 20.84 & 1.43 & 78.75 & 68.42 & 11.75 & 27.00 & 9.75 & 77.90 \\
\hline IBYT-HI-18 & 6 & 21.78 & 1.59 & 77.50 & 69.17 & 13.56 & 22.13 & 9.04 & 72.13 \\
\hline IBYT-HI-19 & 6 & 24.59 & 1.55 & 76.00 & 75.25 & 13.75 & 20.13 & 8.43 & 63.65 \\
\hline IBYT-HI-20 & 6 & 23.02 & 1.41 & 68.00 & 72.75 & 12.13 & 23.25 & 9.28 & 71.83 \\
\hline IBYT-HI-21 & 6 & 21.88 & 1.61 & 74.50 & 82.08 & 12.88 & 28.00 & 10.00 & 74.30 \\
\hline IBYT-HI-22 & 6 & 19.56 & 1.59 & 77.75 & 76.67 & 13.13 & 21.00 & 10.05 & 78.65 \\
\hline Rihane-03 & 6 & 19.19 & 1.46 & 70.25 & 69.92 & 14.13 & 30.75 & 7.43 & 64.60 \\
\hline VMorales & 6 & 19.97 & 1.74 & 75.75 & 73.08 & 13.30 & 26.75 & 8.80 & 72.88 \\
\hline Veslets & 6 & 21.27 & 1.37 & 74.25 & 82.00 & 12.38 & 24.25 & 9.25 & 75.55 \\
\hline Mean & & 20.22 & 1.44 & 74.77 & 77.30 & 12.90 & 27.26 & 9.33 & 62.26 \\
\hline Minimum & & 16.70 & 1.03 & 68.00 & 68.17 & 11.25 & 20.13 & 7.43 & 26.73 \\
\hline Maximum & & 24.59 & 1.79 & 79.00 & 86.50 & 14.50 & 35.50 & 10.63 & 78.75 \\
\hline CV. \% & & 10.33 & 14.62 & 3.60 & 7.37 & 7.12 & 14.90 & 8.16 & 31.74 \\
\hline LSD $0.05 \%$ & & 2.47 & 0.22 & 3.56 & 7.21 & 1.35 & 2.32 & 1.29 & 4.28 \\
\hline
\end{tabular}


Table 1. continued

\begin{tabular}{|c|c|c|c|c|c|c|c|c|}
\hline Lines & $\begin{array}{l}\text { Grain number } \\
\text { per spike }\end{array}$ & $\begin{array}{l}\text { Grain weight } \\
\text { per spike, g }\end{array}$ & $\begin{array}{l}\text { Number of fertile } \\
\text { tillers per plant }\end{array}$ & $\begin{array}{l}\text { Grain yield, } \\
\mathrm{g} / 2.25 \mathrm{~m}^{2}\end{array}$ & $\begin{array}{c}1000 \text { grains } \\
\text { weight, } g\end{array}$ & $\begin{array}{l}\text { Powdery } \\
\text { mildew, \% }\end{array}$ & Net blotch, \% & Stripe rust, \% \\
\hline IBYT-HI-1 & 21.58 & 1.34 & 2.96 & 821.25 & 53.06 & 20.00 & 13.75 & 6.25 \\
\hline IBYT-HI-2 & 53.50 & 2.98 & 2.11 & 574.75 & 39.15 & 10.00 & 16.25 & 21.25 \\
\hline IBYT-HI-3 & 46.25 & 2.12 & 2.22 & 287.50 & 36.50 & 10.00 & 45.00 & 5.00 \\
\hline |BYT-HI-4 & 48.00 & 2.15 & 2.45 & 486.25 & 44.13 & 9.50 & 35.00 & 38.75 \\
\hline IBYT-HI-5 & 46.75 & 2.23 & 2.45 & 633.75 & 46.33 & 12.50 & 28.75 & 36.25 \\
\hline IBYT-HI-6 & 41.00 & 1.90 & 3.05 & 988.00 & 41.78 & 18.75 & 13.75 & 11.25 \\
\hline IBYT-HI-7 & 24.00 & 1.37 & 3.19 & 903.50 & 52.79 & 10.00 & 26.25 & 8.00 \\
\hline IBYT-HI-8 & 48.63 & 2.55 & 2.32 & 591.50 & 43.83 & 9.50 & 23.75 & 11.25 \\
\hline IBYT-HI-9 & 48.50 & 2.36 & 2.66 & 797.50 & 41.55 & 16.25 & 20.00 & 10.00 \\
\hline IBYT-HI-10 & 57.50 & 2.74 & 2.42 & 668.75 & 42.33 & 5.00 & 27.50 & 7.50 \\
\hline IBYT-HI-11 & 38.25 & 2.26 & 2.36 & 529.25 & 46.20 & 5.50 & 32.50 & 11.25 \\
\hline IBYT-HI-12 & 22.73 & 1.31 & 2.39 & 620.75 & 48.53 & 8.75 & 17.50 & 10.00 \\
\hline IBYT-HI-13 & 18.35 & 1.27 & 2.25 & 597.00 & 55.45 & 10.00 & 23.75 & 5.00 \\
\hline IBYT-HI-14 & 22.60 & 1.29 & 3.12 & 837.50 & 54.53 & 21.75 & 27.50 & 5.00 \\
\hline IBYT-HI-15 & 21.95 & 1.24 & 2.22 & 345.00 & 52.95 & 25.00 & 30.00 & 20.00 \\
\hline IBYT-HI-16 & 41.25 & 2.08 & 2.41 & 434.25 & 44.60 & 12.50 & 16.25 & 10.00 \\
\hline IBYT-HI-17 & 49.00 & 2.46 & 2.06 & 280.00 & 40.28 & 10.50 & 28.75 & 5.00 \\
\hline IBYT-HI-18 & 39.75 & 1.91 & 2.55 & 448.50 & 48.92 & 21.25 & 35.00 & 6.25 \\
\hline IBYT-HI-19 & 43.00 & 1.89 & 2.45 & 380.00 & 41.83 & 15.00 & 32.50 & 23.25 \\
\hline IBYT-HI-20 & 49.75 & 2.37 & 2.52 & 730.00 & 50.75 & 5.00 & 47.50 & 7.50 \\
\hline IBYT-HI-21 & 42.75 & 2.41 & 2.53 & 701.25 & 40.13 & 8.75 & 33.75 & 13.75 \\
\hline IBYT-HI-22 & 53.75 & 2.35 & 2.01 & 564.50 & 32.60 & 5.00 & 21.25 & 10.00 \\
\hline Rihane-03 & 44.50 & 2.04 & 2.03 & 544.75 & 45.30 & 5.00 & 26.25 & 12.50 \\
\hline VMorales & 45.75 & 2.48 & 2.12 & 661.25 & 50.19 & 6.25 & 42.50 & 41.25 \\
\hline Veslets & 50.00 & 2.15 & 2.52 & 738.75 & 42.18 & 9.50 & 50.00 & 23.75 \\
\hline Mean & 40.76 & 2.05 & 2.45 & 614.62 & 47.15 & 11.65 & 28.60 & 14.40 \\
\hline Minimum & 18.35 & 1.24 & 2.01 & 280.00 & 32.6 & 5.00 & 13.75 & 5.00 \\
\hline Maximum & 57.50 & 2.98 & 3.19 & 988.00 & 55.45 & 25.00 & 50.00 & 41.25 \\
\hline CV. \% & 28.77 & 24.16 & 13.43 & 30.64 & 8.16 & 49.96 & 35.51 & 26.04 \\
\hline LSD 0.05\% & 4.12 & 0.32 & 0.42 & 58.98 & 6.15 & 7.54 & 12.50 & 8.52 \\
\hline
\end{tabular}

among the studied barley genotypes. The number of fertile spikelets in barley is greatly influenced by environmental conditions (Voltas et al., 1998; Rajala et al., 2011; Dimova, 2015)

Maximum grain weight per spike 2,98 g was recorded in IBYT$\mathrm{HI}-7$ and the minimum 1,24 $\mathrm{g}$ in IBYT-HI-22.

The tiller number ranged from 1.24 to 3.19 , and the genotype IBYT-HI-7 had the maximum tiller number while genotype IBYT-HI15 had the minimum tiller number. According to Naz et al. (2014), tiller number per plant is a major determinant of yield in barley.

The highest grain yield of three check varieties had Veslets. Significantly higher grain yield compared to Veslets was recorded in IBYT-HI-6, IBYT-HI-7 and IBYT-HI-14. The 1000 grain weight ranged from $32.6 \mathrm{~g}$ (IBYT-HI-22) to $55.45 \mathrm{~g}$ (IBYT-HI-13). Athousand grain weight is one of the major yield components having direct effect on the final yield (Pasam et al., 2012).

In different genotypes the percentage of powdery mildew infection varied from 5.00 to 25.00 . IBYT-HI-10, IBYT-HI-20, IBYT$\mathrm{HI}-22$ and Rihane-03 showed high level of tolerance to powdery mildew in field conditions.
The range of infection with net blotch was from $13.75 \%$ to $50.00 \%$. Lines IBYT-HI-1 and IBYT-HI-6 exhibited good resistance to net blotch (below 15.0\%). Lines IBYT-HI-2, IBYT-HI-12 and IBYT$\mathrm{HI}-16$ were moderately susceptible (15.1-25.0\%) and the rest of the studied lines and check varieties were susceptible to net blotch.

The low infection with stripe rust was observed in IBYT-HI-3, IBYT-HI-13, IBYT-HI-14 and IBYT-HI-17 (up to 5\%). The highest rate of infection with stripe rust was recorded in VMorales $(41.25 \%)$, IBYT-HI-4 (38.75\%) and IBYT-HI-4 (36.25\%).

The correlations between the studied traits are presented in Table 2. Flag leaf length had positive correlation with the spikelet number per spike ( $r=0.806)$, grain number per spike $(r=0.714)$ and grain weight per spike $(r=0.722)$ and a negative correlation with peduncle length ( $r=-0.602), 1000$ grain weight $(r=-0.616)$ and stripe rust tolerance $(r=-0.473)$. Plant height showed positive and significant correlation with spike length $(r=0.501)$. Spike length was positively associated with tolerance to net blotch $(r=0.512)$. Peduncle length showed positive and significant correlation with 1000 grain weight $(r=0.571)$ and significant, but negative correlation 
Table 2. Correlation coefficients among 16 traits of 25 barley genotypes (2015-2016)

\begin{tabular}{|c|c|c|c|c|c|c|c|c|c|c|c|c|c|c|c|}
\hline Trait & FLW & $\mathrm{DH}$ & $\mathrm{PH}$ & SL & $\mathrm{AL}$ & $P L$ & SNS & GNS & GWS & $\mathrm{TN}$ & GY & TGW & PM & NB & SR \\
\hline FLL & -0.012 & -0.316 & 0.141 & 0.161 & 0.259 & -0.180 & 0.096 & 0.117 & 0.100 & 0.002 & -0.183 & 0.018 & -0.260 & -0.179 & -0.149 \\
\hline FLW & 1 & 0.069 & -0.291 & -0.360 & 0.330 & $-0.602^{* *}$ & ${ }^{*} 0.806^{* *}$ & $0.714^{* *}$ & $0.722^{* *}$ & -0.385 & -0.156 & $-0.616^{* *}$ & * 0.182 & -0.223 & $-0.473^{*}$ \\
\hline $\mathrm{DH}$ & & 1 & 0.135 & 0.002 & 0.157 & 0.045 & -0.033 & -0.09 & -0.047 & 0.021 & -0.105 & -0.243 & -0.238 & 0.342 & -0.004 \\
\hline $\mathrm{PH}$ & & & 1 & $0.501^{*}$ & -0.222 & 0.284 & -0.163 & -0.087 & 0.002 & 0.177 & 0.163 & -0.069 & 0.107 & 0.322 & 0.079 \\
\hline SL & & & & 1 & -0.343 & 0.263 & -0.239 & -0.278 & -0.191 & -0.033 & -0.176 & 0.093 & -0.023 & $0.512^{\star *}$ & 0.184 \\
\hline $\mathrm{AL}$ & & & & & 1 & -0.154 & 0.296 & 0.334 & 0.324 & -0.104 & 0.006 & -0.159 & 0.024 & -0.27 & -0.311 \\
\hline PL & & & & & & 1 & $-0.583^{* *}$ & $-0.526^{* *}$ & $-0.444^{*}$ & 0.178 & 0.161 & $0.571^{* *}$ & ${ }^{*}-0.077$ & 0.361 & -0.001 \\
\hline SNS & & & & & & & 1 & $0.933^{* *}$ & $0.878^{* *}$ & $-0.412^{*}$ & -0.247 & $-0.777^{* *}$ & ${ }^{*} 0.401^{*}$ & -0.272 & -0.208 \\
\hline GNS & & & & & & & & 1 & $0.932^{* *}$ & $-0.435^{*}$ & -0.185 & $-0.778^{* *}$ & * $0.440 *$ & -0.302 & -0.254 \\
\hline GWS & & & & & & & & & 1 & $-0.468^{*}$ & -0.154 & $-0.687^{* *}$ & * $0.472^{*}$ & -0.199 & -0.280 \\
\hline TN & & & & & & & & & & 1 & $0.731^{* *}$ & 0.393 & $-0.511^{* *}$ & * 0.105 & 0.304 \\
\hline GY & & & & & & & & & & & 1 & 0.274 & -0.074 & 0.057 & 0.115 \\
\hline TGW & & & & & & & & & & & & 1 & -0.292 & 0.045 & 0.087 \\
\hline PM & & & & & & & & & & & & & 1 & -0.230 & -0.043 \\
\hline NB & & & & & & & & & & & & & & 1 & 0.238 \\
\hline
\end{tabular}

FLL -flag leaf length, FLW - flag leaf width, PH - plant height; SL - spike length, AL - awn length, PL - peduncle length,

SNS - spikelet number per spike, GNS - grain number per spike, GWS - grain weight per spike, TN - tiller number per plant, GY - grain yield; TGW - 1000 grain weight; PM - powdery mildew, NB - net blotch, SR - stripe rust.

with the spikelet number per spike ( $r=-0.583)$, grain number per spike $(r=-0.526)$ and grain weight per spike $(r=-0.444)$. Spikelet number per spike had a positive correlation with grain number per spike ( $r=0.933)$, grain weight per spike $(r=0.878)$ and powdery mildew tolerance $(r=0.401)$ and a negative correlation with number of fertile tillers per plant $(r=-0,412)$ and 1000 grain weight $(r=-0.777)$. Grain number per spike was positively associated with grain weight per spike ( $r=0.932)$ and powdery mildew tolerance $(r=0.440)$ and negatively with 1000 grain weight $(r=-0.778)$ and number of fertile tillers per plant $(r=-0.435)$. Grain weight per spike had a negative correlation with number of fertile tillers per plant $(r=-0.468)$ and 1000 grain weight $(r=-0.687)$ and a positive correlation with powdery mildew tolerance $(r=0.472)$. Grain yield had a positive and significant correlation with number of tillers per plant $(r=0.731)$. The similar significant positive association among yield and number of tillers was also observed by Singh et al. (1987), Hosin Babaiy et al. (2011) and Mohtashami (2015)

The results of our study showed that lines from ICARDA High Input Barley Program - 2015 have valuable traits under the conditions of Southeast Bulgaria and can be utilized for future breeding programs to obtain improved barley varieties.

\section{Conclusion}

Significant differences between lines for all studied traits were found. Grain yield had a significant positive correlation with the number of fertile tillers per plant. Lines possessing higher grain yield (IBYT-HI-6, IBYT-HI-7, IBYT-HI-14), shorter stem (IBYT-HI-1, IBYTHI-5, IBYT-HI-13, IBYT-HI-17, IBYT-HI-18, IBYT-HI-20), better tolerance to net blotch (IBYT-HI-1, IBYT-HI-6) and stripe rust (IBYT$\mathrm{HI}-3$, IBYT-HI-13, IBYT-HI-14 and IBYT-HI-17) than the Bulgarian check variety Veslets were identified. These genotypes can, therefore, be used in the breeding program for the improvement of spring barley.

\section{References}

Asseng S and van Herwaarden AF, 2003. Analysis of the benefits to wheat yield from assimilates stored prior to grain filling in a range of environments. Plant Soil, 256, 217-229.

Condon F, Gustus C, Rasmusson D and Smith K, 2008. Effect of advanced cycle breeding on genetic diversity in barley breeding germplasm. Crop Science, 48, 1027-1036.

Dimova D, 2015. Breeding and genetics studies on productivity of feed barley. Thesis for PhD, Institute of Agriculture, Karnobat, Bulgaria $(\mathrm{Bg})$.

Gocheva M and Vulchev D, 2014. Characterisation of winter malting barley cultivar Kuber. Scientific works of the Institute of Agriculture, Karnobat, 3, 71-76 (Bg).

Hosin babaiy A, Aharizad S, Mohammadi A and Yarnia M, 2011. Survey, Correlation of Yield and Yield Components in 40 Lines Barley (Hordeum vulgare L.) in Region Tabriz. Middle-East Journal of Scientific Research, 10, 149-152.

Mikel MA and Kolb FL, 2008. Genetic diversity of contemporary North American barley. Crop Sscience, 48, 1399-1407.

Mohtashami R, 2015. The Correlation study of important barley agronomic traits and grain yield by Path Analysis. Biological Forum An International Journal, 7, 1211-1219.

Naz AA, Ehl A, Pillen K and León J, 2012. Validation for rootrelated quantitative trait locus effects of wild origin in the cultivated background of barley (Hordeum vulgare L.). Plant Breeding, 131, 392-398.

Niari Khamssi N and Najaphy A, 2012. Agro-morphological and phenological attributes under irrigated and rain-fed conditions in bread wheat genotypes. African Journal of Agriculture Research, 7, 51-57.

Olesen JE, Trnka M, Kersebaum KC, Skjelvag AO, Seguin B, Peltonen-Sainio P, Rossi F, Kozyra J and Micale F, 2011. Impacts and adaptation of European crop production systems to climate change. European Journal of Agronomy, 34, 96-112. 
Pasam RK, Sharma R, Malosetti M, Van Eeuwijk FA, Haseneyer G, Kilian and Graner A, 2012. Genome-wide association studies for agronomical traits in a world wide spring barley collection. BMC Plant Biology 12:16, http://www.biomedcentral.com/14712229/12/16

Penchev P and Zarkov B, 2004. Climate specificities in Karnobat in the 20th century. Nature of the Karnobat region, pp. 101-104 (Bg).

Popova T, Valcheva D and Vulchev D, 2009. Evaluation of the genotype similarity in two-rowed winter barley genotypes resistant to loose smut. Field Crops Studies, V, 93-99.

Rajala A, Hakala K, Mäkelä P and Peltonen-Sainio P, 2011. Drought effect on grain number and grain weight at spike and spikelet level in six-row spring barley. Journal of Agronomy and Crop Science, 197, 103-112.

Singh MK, Pandey RL and Singh RP, 1987. Correlation and path coefficient analysis in barley grown on saline soil. Current
Agriculture Research, 11, 55-58.

SPSS Inc., 2007. SPSS for Windows. Release 16.0.SPSS Inc. Chicago, IL. USA.

Valcheva D, Vulchev Dr, Popova T, Dimova D, Ozturk I and Kaya $\mathbf{R}, 2013$. Productive abilities of Bulgarian and introduced varieties and lines barley in Southeast Bulgaria conditions. Scientific works of the Institute of Agriculture, Karnobat, 2, 39-48 (Bg).

Voltas J, Romagosa I and Araus JL, 1998. Growth and Final Weight of Central and Lateral Barley Grains under Mediterranean Conditions as Influenced by Sink Strength. Crop Science, 38, 84-89. Vulchev D, Valcheva D, Gocheva M and Murani I, 2009. Adaptability of promising winter barley lines from Hungary to the conditions of South-east Bulgaria. Field Crops Studies, V, 101-109. Zadoks JC, Chang TT and Konzak CF, 1974. A decimal code for the growth stages of cereals. Weed Research, 14, 415-421. 


\section{Genetics and Breeding}

Variation in the agronomic and morphological traits in spring barley

N. Dyulgerov, B. Dyulgerova

Study on the loss of accuracy of AC method for milk yield control in sheep

D. Dimov, P. Zhelyazkova, A. Vuchkov

Hordein polymorphism between spring barley cultivars by SDS-PAGE electrophoresis

N. Neykov, S. Doneva

\section{Nutrition and Physiology}

Comparative study of rapeseed, monofloral types and multifloral honey by some physico-chemical parameters

I. Zhelyazkova, S. Lazarov

Body condition score, nonesterified fatty acids and beta-hydroxybutyrate concentrations in goats with subclinical ketosis

V. Marutsova, R. Binev

\section{Production Systems}

Lucrative status of improved dual purpose cowpea (Vigna unguiculata L., Walp) in Damboa, Borno State, North-Eastern Nigeria

B.H. Gabdo

Study on the emptying time of grain harvester hoppers

K. Trendafilov, N. Delchev, B. Kolev, G. Tihanov

Length of the growing season and yield in Triticum monococcum L., in accordance with the growing conditions

S. Stamatov, E. Valchinova, G. Desheva, K. Uzundzhalieva, P. Chavdarov, T. Cholakov, B. Kyosev, R.

Ruseva, N. Velcheva

Productivity of durum wheat cultivar Predel at nitrogen-phosphorous fertilization

L. Plescuta

Effect of the herbicide treatment dose on the weed infestation in common winter wheat

Z. Petrova

Evaluation of some technological properties of Caucasian ram wool

D. Pamukova, G. Staykova, N. Stancheva, D. Panayotov 


\section{Agriculture and Environment}

Saved $\mathrm{CO}_{2}$ emissions by using renewable sources for hot water yield in Bulgarian dairy farms

R. Georgiev, R. Slavov, K. Peychev, D. Georgiev, S. Apostolov, J. Ellingsen, J. Tønnesen

Inventory of the legal base for reclamation of lands disturbed by open-cast mining in Bulgaria

M. Banov, V. Tzolova, I. Kirilov

Taxonomic composition of phytoplankton in Black Sea area in front of the Cape Galata (2008-2016)

D. Klisarova, D. Gerdzhikov

Biodiversity of the macrozoobenthos in some protected marine areas along Bulgarian Black Sea coast

E. Petrova, S. Stoykov

Heavy metals in organs of gudgeon (Gobio gobio L.) from Vardar River, R. Macedonia

R. Nastova, V. Kostov, I. Uslinovska

Product Quality and Safety

Mathematical methods for assessment and analysis of honey yield data for Bulgaria and the

N. Keranova

Carcass traits and meat quality of different slow growing and fast growing broiler chickens

M. Oblakova, N. Mincheva, P. Hristakieva, I. Ivanova, M. Lalev, Sv. Georgieva

Role and importance of the awareness for whey in dairy sector at an international level 


\section{Instruction for authors}

\section{Preparation of papers}

Papers shall be submitted at the editorial office typed on standard typing pages (A4, 30 lines per page, 62 characters per line). The editors recommend up to 15 pages for full research paper ( including abstract references, tables, figures and other appendices)

The manuscript should be structured as follows: Title, Names of authors and affiliation address, Abstract, List of keywords, Introduction, Material and methods, Results, Discussion, Conclusion, Acknowledgements (if any), References, Tables, Figures.

The title needs to be as concise and informative about the nature of research. It should be written with small letter /bold, 14/ without any abbreviations.

Names and affiliation of authors The names of the authors should be presented from the initials of first names followed by the family names. The complete address and name of the institution should be stated next. The affiliation of authors are designated by different signs. For the author who is going to be corresponding by the editorial board and readers, an E-mail address and telephone number should be presented as footnote on the first page. Corresponding author is indicated with *

Abstract should be not more than 350 words. It should be clearly stated what new findings have been made in the course of research. Abbreviations and references to authors are inadmissible in the summary. It should be understandable without having read the paper and should be in one paragraph.

Keywords: Up to maximum of 5 keywords should be selected not repeating the title but giving the essence of study.

The introduction must answer the following questions: What is known and what is new on the studied issue? What necessitated the research problem, described in the paper? What is your hypothesis and goal?

Material and methods: The objects of research, organization of experiments, chemical analyses, statistical and other methods and conditions applied for the experiments should be described in detail. A criterion of sufficient information is to be possible for others to repeat the experiment in order to verify results.

Results are presented in understandable tables and figures, accompanied by the statistical parameters needed for the evaluation. Data from tables and figures should not be repeated in the text. Tables should be as simple and as few as possible. Each table should have its own explanatory title and to be typed on a separate page. They should be outside the main body of the text and an indication should be given where it should be inserted.

Figures should be sharp with good contrast and rendition. Graphic materials should be preferred. Photographs to be appropriate for printing. Illustrations are supplied in colour as an exception after special agreement with the editorial board and possible payment of extra costs. The figures are to be each in a single file and their location should be given within the text.

Discussion: The objective of this section is to indicate the scientific significance of the study. By comparing the results and conclusions of other scientists the contribution of the study for expanding or modifying existing knowledge is pointed out clearly and convincingly to the reader. Conclusion: The most important consequences for the science and practice resulting from the conducted research should be summarized in a few sentences. The conclusions shouldn't be numbered and no new paragraphs be used. Contributions are the core of conclusions. References:

In the text, references should be cited as follows: single author: Sandberg (2002); two authors: Andersson and Georges (2004); more than two authors: Andersson et al.(2003). When several references are cited simultaneously, they should be ranked by chronological order e.g.: (Sandberg, 2002; Andersson et al., 2003; Andersson and Georges, 2004).

References are arranged alphabetically by the name of the first author. If an author is cited more than once, first his individual publications are given ranked by year, then come publications with one co-author, two co-authors, etc. The names of authors, article and journal titles in the Cyrillic or alphabet different from Latin, should be transliterated into Latin and article titles should be translated into English. The original language of articles and books translated into English is indicated in parenthesis after the bibliographic reference $($ Bulgarian $=\mathrm{Bg}$, Russian $=\mathrm{Ru}$, Serbian $=\mathrm{Sr}$, if in the Cyrillic, Mongolian =
Mo, Greek = Gr, Georgian = Geor., Japanese $=\mathrm{Ja}$, Chinese $=\mathrm{Ch}$, Arabic $=\mathrm{Ar}$, etc.)

The following order in the reference list is recommended:

Journal articles: Author(s) surname and initials, year. Title. Full title of the journal, volume, pages. Example:

Simm G, Lewis RM, Grundy B and Dingwall WS, 2002. Responses to selection for lean growth in sheep. Animal Science, 74, 39-50

Books: Author(s) surname and initials, year. Title. Edition, name of publisher, place of publication. Example:

Oldenbroek JK, 1999. Genebanks and the conservation of farm animal genetic resources, Second edition. DLO Institute for Animal Science and Health, Netherlands.

Book chapter or conference proceedings: Author(s) surname and initials, year. Title. In: Title of the book or of the proceedings followed by the editor(s), volume, pages. Name of publisher, place of publication. Example:

Mauff G, Pulverer G, Operkuch W, Hummel K and Hidden C, 1995. C3variants and diverse phenotypes of unconverted and converted C3. In: Provides of the Biological Fluids (ed. $\mathrm{H}$. Peters), vol. 22, 143-165, Pergamon Press. Oxford, UK.

Todorov N and Mitev J, 1995. Effect of level of feeding during dry period, and body condition score on reproductive performance in dairy cows, IX $X^{\text {th }}$ International Conference on Production Diseases in Farm Animals, September 11-14, Berlin, Germany.

Thesis:

Hristova D, 2013. Investigation on genetic diversity in local sheep breeds using DNA markers. Thesis for PhD, Trakia University, Stara Zagora, Bulgaria, (Bg).

The Editorial Board of the Journal is not responsible for incorrect quotes of reference sources and the relevant violations of copyrights.

\section{Animal welfare}

Studies performed on experimental animals should be carried out according to internationally recognized guidelines for animal welfare. That should be clearly described in the respective section "Material and methods". 


\section{AGRICULTURAL \\ SCIENCE AND TECHNOLOGY}

Volume 9, Number 4 December 2017
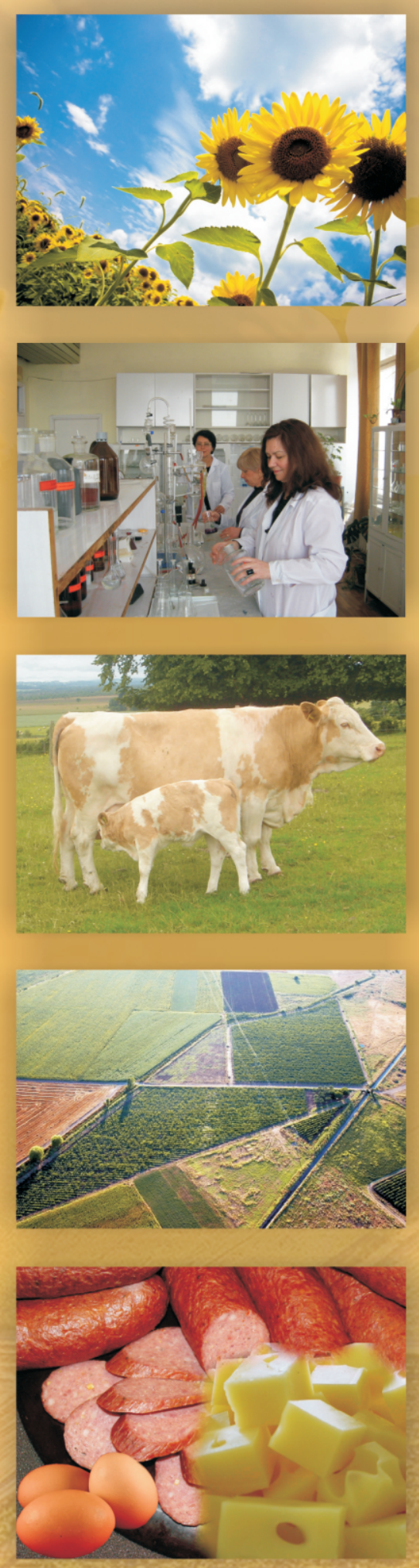

Journal web site: 